sciendo Порівняльна професійна педагогіка 8(2)/2018 Comparative Professional Pedagogy 8(2)/2018

DOI: $10.2478 /$ rpp-2018-0031

Postgraduate Student, TETIANA HORETKO

Institute for Pedagogical Education and Adult Education of the National Academy of Pedagogical Sciences of Ukraine

Address: 9 Berlinskyi St., Kyiv, 04060, Ukraine

E-mail: t.a.g@i.ua

\title{
TRENDS IN PROFESSIONAL TRAINING OF IT MANAGERS IN THE GLOBAL EDUCATIONAL SPACE
}

\begin{abstract}
Modern trends in professional training of IT managers in the global educational space have been characterized. Practical and theoretical aspects of global trends in modern education development - convergence (internationalization) and divergence - have been analyzed (including updating the content of education, quantitative and qualitative changes in the student population, competition among educational institutions, partnership with businesses), and economic and demographic factors behind them are outlined. Trends in general professional training of managers (diversification of educational institutions, differentiation of educational business programs, close ties between the system of managers' training, $R \& D$ and businesses) and IT managers specifically (with regard to the multiple nature of IT management and Ukraine's IT segment specificity) have been detailed. Special emphasis has been given to IT managers' foreign language competence. The range of skills that IT managers need to have in order to meet modern labor market requirements at both national and international levels has been analyzed. It has been concluded that professional training of IT managers is taking on a great significance in the view of modern labor market needs, thus proving further research of IT management specifics and possible ways to expand existing IT management curricula to be a vital task. It has been substantiated that IT managers are not only technical specialists but also managers, they should be ready for self-improvement in this direction too - know and apply innovative approaches to strategic business planning and personnel management, monitor legislative changes, etc. As the sector of IT management sees bright prospects and demand for IT managers keeps growing, professional training of them is taking on a great significance.
\end{abstract}

Keywords: globalization, internationalization of education, professional education and training, educational space, information technology, management, IT-manager, trends.

\section{INTRODUCTION}

The impact of information technology on the global economy has considerably increased over the past decades. The information technology sector started serving as a powerful resource of the international market, contributing much to the process of globalization. It is evident that effective management of IT resources and consequently high-quality education of experts in management of these resources - IT managers - is taking on a greater significance. Since IT management finds itself at the intersection of two fundamental disciplines - management and information technology, professional training of IT managers should cover both directions with regard to their specificity.

THE AIM OF THE STUDY

The aim of this study is to analyze trends in professional training of IT managers in the global educational space. 
Sciendo Порівняльна професійна педагогіка 8(2)/2018

Comparative Professional Pedagogy 8(2)/2018

\section{THEORETICAL FRAMEWORK AND RESEARCH METHODS}

In any field, the content of professional training continuously transforms to meet the market requirements. In the first place, it applies to dynamically developing segments, including IT management. Various aspects of foreign professional training practices were studied by a lot of scientists, e.g. S. Hryschenko, T. Levchenko, N. Nychkalo, O. Oleinikova, L. Pukhovska, M. Weintraub. Specific features of managers' professional training were analyzed by L. Bazavlutska, N. Dudnik, O. Elbrecht, O. Lavrentieva, A. Shegda, O. Uzun et al. At the same time, the field of IT managers' professional training still needs further study.

For the purpose of this research, a range of general scientific methods (including study and analysis of reference, scientific, educational print and on-line sources, statistics) as well as comparative, systematization and generalization methods were applied.

\section{RESULTS}

Current trends in education development can be considered at several levels. Such macro trends as convergence (internationalization) and divergence of education are observed in a number of countries and are embodied in both theoretical aspects (continuous updating of learning content) and practice (a rise in the number of students in higher educational institutions, extension of compulsory education, diversification of educational institutions, higher teaching standards, life-long learning) (Levchenko, 2007). At the same time, according to the British Council (British Council, 2012), the growth rate of the global tertiary education sector will decrease (from 5-6 per cent a year over the previous decade to 1.4 per cent in the coming years) due to demographic and economic slowdown. This factor is also behind the slower growth in the number of students studying abroad. On the other hand, the international cooperation keeps strengthening in the segments of scientific research and teaching. This indicates that internationalization of tertiary education is moving into a new stage, where the weight of international research and delivery of education will be comparable with that of international student mobility flows, the British Council forecasts. Besides, due to powerful emerging economies (China, India, Brazil), there is a shift from the "western concept" of internationalization. Several more tertiary education trends include the emergence of new models of global higher education partnerships and the decrease in investment in higher education in a number of countries that is making higher education institutions engage commercial research activities.

The notion of integration is a determinant in the modern educational space of the European Union: due to it, a range of common European knowledge, skills and values is being developed by students enabling them to realize their potential in the modern European society (Levchenko, 2007).

The processes of internationalization aimed at the common educational space feature synergy of both formal and informal teaching orbits, larger investments in human resource development due to social partners, innovative teaching and learning techniques, more effective mechanisms applied to estimate professional education quality and results (Pukhovska et al., 2015). In their turn, the processes of divergence aim at preserving specificity of national educational systems and depend on historical, cultural, economic and geographic factors, structure of education systems, etc. (Levchenko, 2007).

Leading educational institutions of the United Kingdom (e.g. the University of Oxford and the British Council) consider internationalization to be one of the most powerful trends in modern tertiary education (British Council, 2012; University of Oxford, 2017). It is determined by such factors as higher teaching standards, fiercer competition between educational institutions, need in the specialists able to work on not only national but also 
global markets, development of international scientific cooperation (British Council, 2012). The Bologna Process is one of the most meaningful results of education internationalization.

There are several more general development trends typical of the European educational space: learner-centered approaches, educational autonomy and a wide use of international technology (Levchenko, 2007).

Several trends of general professional education are most typical of managers' professional education. They are: diversification of educational institutions (emergence of various structures and institutions (both commercial and non-commercial) outside of and within the education system, fiercer competition between them), differentiation of curricula (including widening the range of distance learning courses), intensification of contacts between the system of managers' training, the segment of R\&D and businesses (Uzun, 2001).

It is important to note that being a sub-direction of professional education of managers, professional education of IT managers is still in its infancy and is being influenced by both the trends common for this direction and specific ones.

IT managers are supposed to have a unique set of skills and knowledge about the business segment (economics, project management, budgeting, logistics, negotiating, human resource management), information technology (cyber security, programming, cloud technologies, web design), law (labor and IT regulations), etc. That is why a drift to closer partnership between the professional education segment and the labor market is of vital importance to this job. One of the numerous changes that the world has faced over the past two decades due to information technology is that IT departments of organizations are moving from "IT self-sufficiency toward managed dependencies" (Frenzel, \& Frenzel, 1992), and this management is a function which IT management graduates should be ready to perform. In this context, the partnership between educational institutions and businesses becomes a tool of not only education financing but also mutually beneficial training, development and implementation of joint policies. This partnership enables educational institutions to offer target and innovative curricula, directly involve employers to develop these curricula thus raising their students' employability (European Commission, 2012).

American multinational company Cisco, which is one of the global high-tech leaders, can serve as a striking example of such partnership in the field of IT. Under its business model, it developed a branched training and certification system for network engineers. Cisco certificates are among the most famous and recognized credentials in the computer industry. Cisco Academy has more than 7.8 million students and 22 thousand instructors in 170 countries. Last year alone Cisco cooperated with 30 thousand educational institutions all over the world.

In its report on vocational education and training in Australia (Cisco, 2011), Cisco specifies a range of global trends, including a changing and broadening student base, fiercer competition between education providers, increased demand for new and higher level skills, the global uptake of online and blended learning, and closer cooperation between educational institutions and employers. Cisco also identifies several negative trends in the field of vocational training: weaker signals of demand from industry and high dropout rates. For instance, one in five students in the US and one in seven students in Canada do not make it into the second year of their college courses. That is why a key requirement for high-quality education is that it should anticipate existing production processes and combine traditional instruction with innovations (Weintraub, 2015), which is of special importance for IT specialists' training. 
Sciendo Порівняльна професійна педагогіка 8(2)/2018

Comparative Professional Pedagogy 8(2)/2018

There is one more modern education trend most pronounced in IT segment higher velocity of learning driven by rapid development of digital technologies and emergence of new ones. Since it is one of IT managers' direct functions to monitor new ideas and concepts on the market, estimate their effectiveness and implement them in their companies in case of need, IT managers should be ready for continuous self-perfection. Consequently, when training IT managers, educational institutions should pay special attention to enabling their students to develop as personalities ready for life-long learning.

It is important to note that since IT managers are not only technical specialists but also managers, they should be ready for self-improvement in this direction too - know and apply innovative approaches to strategic business planning and personnel management, monitor legislative changes, etc.

There is one more important aspect of professional training of IT managers that should not go unnoticed - language competence development. The ability to speak foreign languages is a factor for competitiveness in the modern world. The first European Survey on Language Competences carried out by the European Commission in 16 member countries in 2011 showed that pupils' foreign language proficiency was not high enough. For instance, in France only 14 per cent of all pupils reached the level of an independent user of one foreign language at the end of lower secondary education, and in the UK this was only 9 per cent while the target defined by Heads of State is "mother tongue plus two" (European Commission, 2012). A 2017 report by the Spanish Service for the Internationalization of Education (SEPIE) reads that the level of mastery of foreign languages in general and English in particular continues to be the Achilles' heel in Spain, preventing many local institutions from taking further steps toward enlarging their offer of innovative courses in English (SEPIE, 2017). In Ukraine, the ability to communicate in English, which is the language of the international business community, is one of employers' key requirements for IT specialists. This fact is due to peculiarities of Ukraine's IT segment: it is the country's third most lucrative export and makes up 3.4\% of its GDP. Besides, the lion's part of IT professional literature, engineering documents and manuals is in English. In this way, IT managers should be users of English to work even on the national market, not to speak of international ones.

Apart from languages, there are several more specific factors that determine IT managers' activities in the international market and that educational institutions should take into account when training them. In particular, since more and more companies are entering the global market due to globalization and the part of information technology in this process can hardly be overestimated, IT managers working on the global market will need more specific technical and economic expertise than their colleagues in national markets. Educators, education managers and IT experts will have to join efforts to train these specialists. Evidently, this process will require great resources, internationalization of the content of IT managers' education and effective management (Phukan, 1996).

\section{CONCLUSIONS}

In the field of IT management, professional education is influenced by both modern education development trends and specific factors. To meet the labor market needs and raise their graduates' employability, higher educational institutions should expand their IT management curricula with a wide range of business subjects as well as to provide their students with the sound academic IT background, combining traditional and innovative teaching methods, and paying close attention to improvement of self-education skills. Since IT management development is in large part determined by peculiarities of the IT sector dominated by English-language resources, an emphasis should be put on English-language courses. 
The highly dynamic domain of information technology has become a driving force of globalization over the past decades. What concerns education, globalization processes started having an impact on not only student mobility flows, the scope of international cooperation and competition between educational institutions but also curricula: when training IT managers, higher educational institutions should bear in mind the fact that IT management is going beyond national markets. As the sector of IT management sees bright prospects and demand for IT managers keeps growing, professional training of them is taking on a great significance. At the same time, since IT management is still in the formative stage, further research of its specifics and the possible ways to expand existing IT management curricula becomes a vital task.

\section{REFERENCES}

1. British Council. (2012). The shape of things to come: higher education global trends and emerging opportunities to 2020. Retrieved from https:/www.britishcouncil.org/ sites/default/files/the_shape_of_things_to_come_-_higher_education_global_trends_and_ emerging opportunities to $20 \overline{2} 0$.pdf.

2. Cisco. (2011). Global trends in vocational education and training. Retrieved from https://www.cisco.com/c/dam/global/en_au/solutions/strategy/content/training.pdf.

3. European Commission. (2012). Communication from the Commission to the European Parliament, the Council, the European Economic and Social Committee and the Committee of the Regions: Rethinking Education: Investing in Skills for Better SocioEconomic Outcomes. Retrieved from http://www.cedefop.europa.eu/en/publications-andresources/key-documents.

4. Frenzel, C. W., \& Frenzel, J. C. (1992). Management of information technology: excellence in information systems. Boston, Mass: Boyd \& Fraser Pub. Co.

5. IT-haluz ta telekomunikatsii posidaiut trete mistse v Ukraini za eksportom Kubiv. (2017). Vziato z https://sn.ua/groshi/it-galuz-ta-telekomunikaciyi-posidayut-natretye-misce-v-ukrayini-za-eksportom-kubiv-881768.html.

6. Levchenko, T. I. (2007). Evropeiska osvita: konverhentsia ta dyverhentsia. Vinnytsia: Nova Knyha.

7. Phukan, S. (1996). Global information systems and technology: challenges and opportunities for information systems professionals, Proceedings of the 1996 Information Resources Management Association International Conference on Information Technology Management and Organizational Innovations. Washington, DC: Idea Group Inc.

8. Pukhovska, L. P., Vornachev, A.O., \& Leu, S.O. (2015). Profesiynii rozvutok personal pidpriemstv u krainakh Evropeiskoho. Kyiv: IPTO NAPNU.

9. SEPIE. (2017). The internationalization of higher education in Spain: Reflections and Perspectives. Madrid: Spanish Service for the Internationalization of Education. Retrieved from http:/sepie.es/doc/ comunicacion/publicaciones/SEPIE-ENG internacionalizacion.pdf.

10. University of Oxford. (2017). International trends in higher education 2016-17. Retrieved from http://www.ox.ac.uk/sites/files/oxford/trends\%20in\%20globalisation_WEB.pdf.

11. Uzun, O. E. (2001). Tendentsii pazvitiya podgotovki spetsialisto $\bar{v} v$ oblasti menedgmenta v SSHA, Germanii $i$ Anglii. (Avtoref. dis. kand. ped. nauk). Kazanskiy gosudarstvennyi technologicheskyi universitet, Kazan.

12. Weintraub, M. A., Romanova, A. M., Mosia, I. A., \& Bilokon Ya. Yu. (2015). Modernizatsia zmistu profesiinoi osvity $i$ navchnnia: teoria i practyka. Kyiv: TOV "NVP Poligrafservis". 